\title{
POTENSI DAUN PURING (Codiaeum variegatum) DALAM MENYERAP LOGAM TIMBAL (PB) DENGAN METODE SPEKTROFOTOMETRI SERAPAN ATOM (SSA)
}

\author{
Asriani Suhaenah, St. Maryam, Gusmiati \\ Fakultas Farmasi, Universitas Muslim Indonesia, Makassar \\ Email: asriani.suhaenah@umi.ac.id
}

\begin{abstract}
One type of pollution that must be taken into concern is lead metal $(\mathrm{Pb})$ as an element that is harmful to humans. Croton leaves contain tannin chemical compounds that able to bind lead (Pb). The research aimed to determine to potency of croton leaves as an adsorbent of lead (Pb). The research used a metal content measurement method based on the adsorption of croton leaves by atomic absorption spectrophotometry (AAS). The results showed that the absorption of lead was based on 3 gram concentrations in the samples, namely sample (1) $0.1181 \mathrm{gram}$ of $1.9991 \mu \mathrm{g} / \mathrm{g}$, sample (2) 0.3179 gram of $0.0871 \mu \mathrm{g} / \mathrm{g}$ and sample (3) $0.5117 \mathrm{gram}$ of $0.2171 \mu \mathrm{g} / \mathrm{g}$. in the use of parameter of the sample concentration it is indicated that at mass $0.1181 \mathrm{gram}$, the lead metal content showed a maximum absorption of $1.9991 \mu \mathrm{g} / \mathrm{g}$ sample.
\end{abstract}

Key words : Croton leaves (Codiaeum variegatum), lead $(\mathrm{Pb})$, atomic absorption spectrophotometry (AAS).

\section{PENDAHULUAN}

Secara umum diketahui bahwa logam berat merupakan unsur yang berbahaya, sehingga kontaminasi logam berat di lingkungan merupakan masalah besar. Permasalahan spesifik logam berat di lingkungan adalah terakumulasinya sampai pada rantai makanan tingkat tertinggi, serta meningkatnya sejumlah logam berat, yang menyebabkan peningkatan keracunan pada tanah, udara dan air. ${ }^{2}$

Timbal $(\mathrm{Pb})$ termasuk dalam kelompok logam berat golongan IVA dalam Sistem Periodik Unsur kimia, $\mathrm{Pb}$ merupakan racun syaraf (neuro toxin) yang bersifat kumulatif, destruktif dan kontinu pada sistem haemofilik, kardio- vaskuler dan ginjal. Anak yang telah menderita tokisisitas timbal cenderung menunjukkan gejala hiperaktif, mudah bosan, mudah terpengaruh, sulit ber konsentrasi terhadap lingkungannya termasuk pada pelajaran, serta akan mengalami gangguan pada masa dewasanya nanti yaitu anak menjadi lamban dalam berfikir, biasanya orang akan mengalami keracunan timbal bila ia mengonsumsi timbal sekitar 0,2 sampai $2 \mathrm{mg} /$ hari. $^{1}$

Tanaman mempunyai kemampuan efektif untuk mengatasi atau mengeliminir pencemaran udara yang terjadi di kota, salah satunya adalah tanaman puring. Daun puring terdapat kandungan kimia seperti saponin, tannin dan pada daunnya banyak terdapat stomata yang efektif menyerap timbal $(\mathrm{Pb})$ yang ada di udara. ${ }^{2}$

Dalam penelitian Fitriani (2017), mengenai peranan serbuk daun puring sebagai penyerap ion logam $\mathrm{Pb}(\mathrm{II})$ dari larutannya. ${ }^{2}$ Dimana dalam peneltiannya yaitu mengukur pengaruh massa dan waktu kontak optimum adsorpsi ion logam $\mathrm{Pb}$ (II) dari adsorben yang berasal dari tanaman hias yaitu tanaman 
puring. $^{2}$ Oleh karena itu dilakukan

pengujian potensi daun puring dalam menyerap logam timbal $(\mathrm{Pb})$ dengan menggunakan metode spektrofotometri serapan atom (SSA).

\section{METODE PENELITIAN}

\section{Alat dan Bahan}

Alat yang digunakan yaitu blender (Philips $\AA$ ), Erlenmeyer250 mL (iwaki Pirex®), labu ukur $50 \mathrm{~mL}$ dan $200 \mathrm{~mL}$ (iwaki Pirex®), gelas ukur $50 \mathrm{~mL}$ (iwaki Pirex®), corong, pipet tetes, pipet volum $5 \mathrm{~mL}$,magnetic stirrer (sibata $\AA^{\circledR}$ ), ayakan mesh 60 spektrofotometri serapan atom (Thermo $\AA$ ), dan timbangan analitik (Acis AD-600H). Bahan yang digunakan adalah air suling (aquadest), larutan timbal $(\mathrm{Pb})$ (Certipur $\AA)$ ), asam nitrat pekat (HNO3 P) (Emsure $\left.\left.{ }^{\circledR}\right)\right)$, kertas saring whatman 41 ,sampel tanaman daun puring (Codiaeum variegatum).

\section{Prosedur kerja}

\section{Pengolahan sampel}

Sampel daun puring (Codiaeum variegatum) dicuci bersih dari kotoran yang melekat menggunakan air mengalir untuk menghilangkan debu dan pengotor. Kemudian di iris menjadi potongan keci dan dikeringkan pada suhu ruangan. Daun puring (Codiaeum variegatum) yang telah kering dihaluskan dengan cara diblender tanpa pelarut, kemudian disaring dengan ayakan berukuran 60 mesh. $^{3}$

\section{Pembuatan larutan timbal}

Larutan baku yang digunakan dalam bentuk sediaan cair yaitu 1000 ppm dalam 500 $\mathrm{mL}$, kemudian di encekan hingga 1 ppm (1000 $\mathrm{ppb}) .{ }^{4}$

\section{Pembuatan larutan standar timbal $(\mathrm{Pb})$}

Larutan 1000 ppb dipipet masingmasing sebanyak $0,1 \mathrm{~mL}, 0,2 \mathrm{~mL}, 0,3 \mathrm{~mL}, 0,4$ $\mathrm{mL}$ dan $0,5 \mathrm{~mL}$ dimasukkan kedalam labu ukur
$10 \mathrm{~mL}$ dan dicukupkan hingga tanda batas sehingga diperoleh konsentrasi larutan standar menjadi 10 ppb, 20 ppb, 30 ppb, 40 ppb dan 50 $\mathrm{ppb}^{4}$

\section{Pembuatan larutan kerja}

Larutan 1000 ppb dipipet sebanyak 10 $\mathrm{mL}$ kedalam labu ukur $200 \mathrm{~mL}$ dan dicukupkan volumenya dengan $\mathrm{HNO} 32 \%$ hingga batas tanda dan dihomogenkan sehingga diperoleh larutan stok dengan konsentrasi 50 ppb. $^{4}$

\section{Penentuan panjang gelombang maksimum}

Penentuan panjang gelombang maksimum timbal $(\mathrm{Pb})$ dilakukan dengan melakukan running larutan timbal $(\mathrm{Pb})$ konsentrasi $50 \mathrm{ppb}$, sehingga di asumsikan kadar $\mathrm{Pb}$ yang akan di ujikan berkisar pada rentang kerja optimum $0,5-50 \mu \mathrm{g} / \mathrm{mL}$ yaitu pada panjang gelombang $283.3 \mathrm{~nm} .{ }^{4}$

Pengukuran adsorpsi timbal (pb) pada sampel

Sampel daun puring (Codiaeum variegatum) kering ditimbang sebanyak 0.1181 gram, 0.3179 gram dan 0.5117 gram dimasukkan ke dalam Erlenmeyer $250 \mathrm{~mL}$, masing-masing konsentrasi sampel ditambahkan $50 \mathrm{~mL}$ larutan timbal $50 \mathrm{ppb}$. Dikocok dengan menggunakan stirrer selama 20 menit pada suhu kamar. Pemisahan adsorben dan larutan dilakukan dengan penyaringan menggunakan kertas saring whatman no.41. Kemudian larutan di ukur dengan spektrofotometri serapan atom pada panjang gelombang $283,3 \mathrm{~nm} .{ }^{3}$

\section{HASIL DAN PEMBAHASAN}

Penelitian ini dilakukan untuk mengetahui potensi daun puring (Codiaeum variegatum) dalam menyerap logam timbal $\mathrm{Pb})$ dengan menggunakan metode spektrofotometri serapan atom (SSA 
Potensi Daun Puring (Codiaeum variegatum) Dalam Menyerap Logam Timbal (PB) Dengan Metode Spektrofotometri Serapan Atom (SSA)

Sampel daun puring (Codiaeum variegatum) yang telah kering dihaluskan menggunakan blender kemudian disaring dan diukur partikelnya menggunakan ayakan mesh 60 , hal ini bertujuan untuk membuat luas permukaan dari serbuk lebih besar sehingga daya serapnya terhadap logam timbal $(\mathrm{Pb})$ lebih banyak pada permukaan adsorben. Tahap pertama yang paling penting dilakukan sebelum pengukuran kadar logam timbal pada sampel adalah kalibrasi alat spektrofotometri serapan atom (SSA). Spektrofotometri serpan atom adalah suatu alat instrument yang digunakan untuk mengukur absorbansi logam pada sampel berdasarkan panjang gelombang tertentu tergantung sifat unsur logam yang akan diukur. Dimana tujuan dilakukan kalibrasi adalah untuk memperoleh hasil analisis yang selektif dan valid.

Kurva kalibrasi standar dibuat dari larutan standar dengan 5 perbandingan konsentrasi 10 ppb, 20 ppb, 30 ppb, 40 ppb dan $50 \mathrm{ppb}$ kemudian diukur menggunakan spektrofotometri serapan atom pada panjang gelombang $283,3 \mathrm{~nm}$. Sehingga diperoleh hasil pengukuran seperti yang terlampir pada tabel 1.

Tabel 1. Hasil Pengukuran Absorbansi Larutan Standar Pb Menggunakan Spektrofotometer Serapan Atom Pada Panjang Gelombang 283,3 Nm.

\begin{tabular}{cc}
\hline Konsentrasi $(\mathbf{p p b})$ & Absorbansi \\
\hline 10 & 0.0041 \\
20 & 0.0065 \\
30 & 0.0108 \\
40 & 0.0145 \\
50 & 0.0190 \\
\hline
\end{tabular}

Dari hasil pengukuran absorbansi larutan standar $\mathrm{Pb}$ maka dapat di buat kurva kalibrasi seperti pada gambar 1 yang menunjukkan bahwa semakin tinggi konsentrasi maka nilai absorbansi semakin naik. Kurva tersebut merupakan perbandingan antara konsentrasi yang mewakili sumbu $\mathrm{x}$ dan absorbansi yang mewakili sumbu y. Maka dari hasil kurva kalibrasi kemudian dibuat persamaan garis linear $y=b x+a$. dimana $b$ adalah slope atau nilai kemiringan dan a adalah intersep. Dari kurva kalibrasi standar diperoleh persamaan yaitu $y=0,00036 x+0,0004$. Dengan nilai koefisien korelasi $r=0,998$. Dimana nilai koefisien korelasi menyatakan ukuran kesempurnaan antara nilai absorbansi dan nilai konsentrasi yang membentuk garis lurus, linearitas dikatakan sempurna apabila nilai koefisien korelasi mendekati 1.

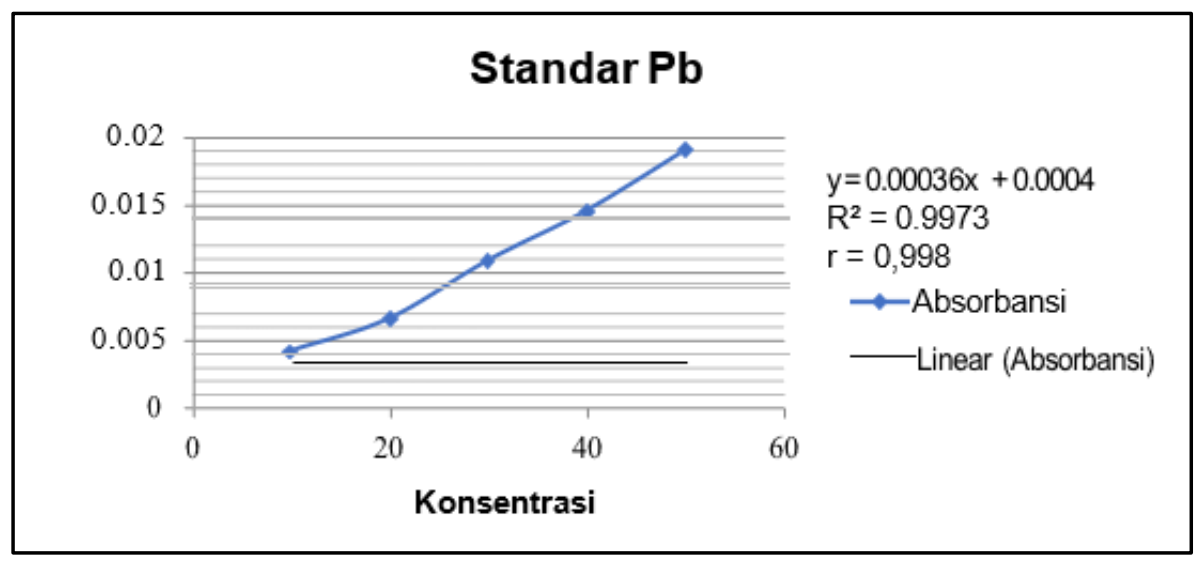




\section{Gambar 1. Kurva kalibrasi standar $\mathrm{Pb}$}

Dari data kurva standar timbal $(\mathrm{Pb})$ diperoleh nilai koefisien korelasi sebesar 0,998 ini berarti titik-titik pada kurva kalibrasi yang dihasilkan sampel mendekati garis linearnya. Oleh karena itu, kurva kalibrasi standar timbal layak untuk dijadikan acuan dalam mengukur kadar logam $(\mathrm{Pb})$ pada sampel. Dari hasil pengukuran kadar logam timbal $(\mathrm{Pb})$ pada sampel daun puring (Codiaeum variegatum) yang telah dihitung dapat dilihat pada tabel 2.

Tabel 2. Kadar $\mathrm{Pb}$ yang terabsorbsi oleh serbuk daun puring (Codiaeum variegatum) dengan konsentrasi awal larutan $\mathrm{Pb} 50 \mathrm{ppb}$ dengan pengukuran alat spektrofotometri serapan atom (SSA).

\begin{tabular}{ccccccc}
\hline Sampel & $\begin{array}{c}\text { Massa } \\
(\mathbf{g r a m})\end{array}$ & Absorbansi & Absorbansi Pb & $\begin{array}{c}\text { Absorbansi } \\
\text { Akhir }\end{array}$ & $\begin{array}{c}\text { Konsentrasi } \\
(\boldsymbol{\mu g} / \mathbf{g})\end{array}$ & $\begin{array}{c}\text { Kadar } \\
(\boldsymbol{\mu} \mathbf{g} / \mathbf{g})\end{array}$ \\
\hline Sampel 1 & 0,1181 & 0,0045 & & 0,0021 & 4,722 & 1,9991 \\
Sampel 2 & 0,3179 & 0,0030 & 0,0024 & 0,0006 & 0,555 & 0,0871 \\
Sampel 3 & 0,5117 & 0,0036 & & 0,0012 & 2,222 & 0,2171 \\
\hline
\end{tabular}

Dari data hasil pengukuran pada tabel tersebut bisa diketahui bahwa konsentrasi adsorben (serbuk daun puring) pada 3 perbandingan konsentrasi dengan menggunakan larutan timbal $(\mathrm{Pb})$ sebagain bahan logam yang akan di serap oleh sampel (serbuk daun puring), dimana konsentrasi larutan timbal $(\mathrm{Pb})$ yang digunakan yaitu $50 \mathrm{ppb}$ dan dilakukan pengadukan selama 20 menit sehingga dapat diperoleh kadar larutan timbal pada 3 konsentrasi gram sampel yaitu pada sampel (1) 0,1181 gram sebanyak 1,9991 $\mu \mathrm{g} / \mathrm{g}$, sampel (2) 0,3179 gram sebanyak 0,0871 $\mu \mathrm{g} / \mathrm{g}$ dan sampel (3) 0,5117 gram sebanyak $0,2171 \mu \mathrm{g} / \mathrm{g}$. Data ini menunjukkan bahwa pada massa 0,1181 gram kadar logam timbal menunjukkan penyerapan maksimum yaitu sebesar 1,9991 $\mu \mathrm{g} / \mathrm{g}$ sampel. Dari data tersebut dapat menunjukkan bahwa penyerapan logam $\mathrm{Pb}$ oleh adsorben dikarenakan adanya kandungan tannin pada sampel daun puring (Codiaeum variegatum) yang dapat menyebabkan adsorben mampu mengikat logam berat. Dimana tannin yang bereaksi pada saat terjadinya penyerapan yaitu unsur
-OH pada struktur tannin akan terlepas dan logam-logam yang akan diserap akan berikatan pada struktur tannin. Sehingga logam-logam timbal berikatan dengan tannin dikarenakan pelapasan unsur - $\mathrm{OH}$ yang ada pada tannin. Proses masuknya unsur $\mathrm{Pb}$ ke dalam jaringan tumbuhan biasa juga melalui xylem ke semua bagian tumbuhan puring sampai ke daun atau dengan cara penempelan partikel tersebut pada daun dan masuk ke dalam jaringan melalui stomata. ${ }^{5}$

\section{KESIMPULAN}

Sampel daun puring (Codiaeum variegatum) dapat berpotensi sebagai tanaman penyerap logam timbal. Kadar logam timbal yang dapat diserap pada sampel daun puring (Codiaeum variegatum) pada massa 0,1181 gram kadar logam timbal menunjukkan penyerapan maksimum yaitu sebesar 1,9991 $\mu \mathrm{g} / \mathrm{g}$ sampel.

\section{DAFTAR PUSTAKA}

1. Dessy G. Pencemaran Logam Berat Timbal (Pb) Di Udara Dan Upaya Penghapusan Bensin Bertimbal. Berita Dirgantara.2012;13(3) :95-99. 
Potensi Daun Puring (Codiaeum variegatum) Dalam Menyerap Logam Timbal (PB) Dengan Metode Spektrofotometri Serapan Atom (SSA)

2. Fitriani, Kurniati T,Hambali. Penyerapan Ion Logam $\mathrm{Pb}$ (li) Dari Larutan Menggunakan Serbuk Daun Puring (Codiaeum variegatum). Jurnal Pendidikan Matematika dan IPA. 2017;1:34-42.

3. Leorita N. Uji Daya Serap ion Logam Berat $\mathrm{Pb}, \mathrm{Cr}$, dan $\mathrm{Cu}$ Dari Limbah Sintesis Menggunakan Biomaterial Daun Jambu Biji dengan Metode Spekrofotometri Serapan Atam (SSA) (Disertasi). Riau: Universitas Islam Negeri Sultan Syarif Kasim,2011; 4749.
4. Lestari WF. Analisis kadar logam merkuri ( $\mathrm{Hg})$ dan timbal $(\mathrm{Pb})$ pada teripang terung (Phyllophoursophorus sp.) asal pantai kenjeran Surabaya secara spektrofotometri serapan atom (SSA) (Skripsi). Malang : Fakultas Sains Dan Teknologi, Universitas Islam Negri Maulana Malik Ibrahim, 2015;33-47.

5. Sulistiana S, dan Setijorini LE. Akumulasi Timbal (Pb) Dan Struktur Stomata Daun Puring. Jurnal Agrosains dan Teknologi. 2016:1(2); 9-22. 